Al Qalam: Jurnal Ilmiah Keagamaan dan Kemasyarakatan

https://jurnal.stiq-amuntai.ac.id/index.php/al-qalam

P-ISSN: 1907-4174; E-ISSN: 2621-0681

DOI : 10.35931/aq.v14i2. 398

\title{
IMPLEMENTASI MEDIA DAN METODE PEMBELAJARAN DALAM PENGUASAAN MATERI FIKIH DI MA AL-KHOIROT
}

\author{
Muhammad Hilmi Fuaidi \\ Mahasiswa, Magister Pendidikan Agama Islam, Pascasarjana UIN Maulana Malik Ibrahim, \\ Malang, Indonesia \\ e-mail: radenhilmi2@gmail.com
}

\begin{abstract}
Abstrak
Implementasi Metode pembelajaran fikih ialah suatu pembelajaran dimana lebih menekankan pada pengalaman, jadi siswa ini diberi kesempatan untuk melakukan sesuatu hal sehingga nantinya ia mendapatkan pengalaman belajar. Tujuan penelitian ini yaitu: pertama, Mengetahui implementasi penguasaan media pembelajaran materi fikih di MA Al-Khoirot. Kedua, Mengetahui implementasi penguasaan metode pembelajaran materi fiqih di MA Al-Khoirot. Ketiga, Mengetahui langkah-langkah implementasi media dan metode pembelajaran mata pelajaran fikih di MA Al-Khoirot. Keempat, Mengetahui faktor-faktor pendukung dalam menerapkan media dan metode pembelajaran mata pelajaran fikih di MA Al-Khoirot. Metode Penelitian disini adalah penelitian kualitatif dengan desain penelitian yang dilakukan adalah penelitian lapangan (field reseach), yaitu penelitian diartikan sebagai cara ilmiah untuk mendapatkan data dengan tujuan dan kegunaan tertentu. Hasil penelitian Implementasi dari penguasaan media pembelajaran materi fikih di MA Al-Khoirot sudah diterapkan namun masih ada kekurangan yaitu guru belum semua menguasai media pembelajaran. Kedua, Untuk implementasi penguasaan metode pembelajaran materi fikih di MA Al-Khoirot sudah dicoba mengunkan semua metode namun pelaksanaannya selalu menggunakan metode caramah. Ketiga, Implemntasi langkah- langkah metode pembelajaran di MA Al-Khoirot, diantaranya: (a)perencanaan, guru membuat RPP termasuk memilih mempersiapkan alat dan media sebelum pembelajaran. b) Pelaksanaan pembelajaran dengan menerapkan apa yang sudah direncanakan dalam RPP, langkah terakhir yaitu evaluasi atau penilaian. Keempat, faktor pendukung dalam penerapan media dan metode pembelajaran diantaranya: inovasi guru dalam menerapkan metode pembelajaran, adanya sumber atau bahan yang mendukung untuk mata pelajaran fikih, dan adanya media untuk mendukung proses pembelajaran fikih dalam pembelajaran, serta alokasi waktu yang tepat pada tiap aktivitas pembelajaranya.
\end{abstract}

Kata Kunci : Implementasi, Media dan Metode, Materi Fikih

\section{PENDAHULUAN}

Pembelajaran yaitu suatu proses pendidikan yang didalamnya terdapat interaksi antara beberapa macam yaitu, pendidik, peserta didik serta materi pembelajaran atau sumber ajar. Dan untuk interaksi tersebut membutuhkan sarana dan prasarana agar tercapai tujuan pembelajaran, meliputi media dan metode

Al Qalam: Jurnal Ilmiah Keagamaan dan Kemasyarakatan Vol. 14, No. 2, Juli-Desember 2020 
dalam pembelajaran. Pada dasarnya pembelajaran adalah suatu kegiatan terencana yang mengkondisiskan atau merangsang seseorang bisa belajar dengan baik dan agar tercapai tujuan pembelajaran yang telah dirumuskan, maka kegiatan pembejaran akan merubah tingkah laku seseorang dan menyampaikan pengetahuan melalui kegiatan pembejaran.

Seorang pendidik harus menguasai media-media pelajaran untuk terlaksananya suatu pembelajaran yang efektif dan efisien, sehingga siswa tidak bosan dengan kegiatan (proses pembelajaran yang monoton). Oleh karena itu perlu adanya prinsip-prinsip dalam menggunakan media pembelajaran.

Menurut Taksonomi Leshin dkk, Adapun prinsip-prinsip penggunaan dan pengembangan media pembelajaran diantaranya yaitu: pertama, Media manusia (Guru, Instruktur, Main Peran, Kegiatan kelompok). Kedua, Media Cetakan (Buku, buku kerja/latihan, dan lembaran). Ketiga, Media Visual (Grafik, peta, figur/gambar, transparasi, Film bingkai dan slide). Kelima, Media audio visual (Vidio, film, slide bersama tape, tv ). keenam, Dan Media komputer ( Pengajaran dengan bantuan komputer/Laptop dan video interaktif ). ${ }^{1}$ Jadi salah satu fungsi utama dari media pembelajaran adalah sebagai bahan alat bantu mengajar yang mempengaruhi hasil, kondisi, dan lingkungan belajar yang diterakan oleh pendidik. ${ }^{2}$

Hasil observasi Peneliti bahwa siswa MA Al-Khoirot Desa Karangsuko Kecamatan Pagelaran Kabupaten Malang Tahun Pelajaran 2019/2020, memang masih banyak mengalami kendala dalam pelaksanaan menggunakan media dan metode pembelajaran dalam pembelajarannya.

Media pembelajaran digunakan sebagai sumber belajar dan sarana guru untuk menyampaiakan kegiatan belajar mengajar di sekolah, kepada peserta didik, oleh karna itu dengan menggunakan media pembelajaran peserta didik diharapkan akan dengan mudah menerima pembelajaran yang telah disampaikan oleh pendidik.

Peserta didik sebagai generasi lanjutan yang diharapkan dapat melanjutkan perjuangan bangsa ini, sesuai dengan tujuan pendidikan nasional yang menciptakan generasi yang cerdas, kreatif dan mandiri. Mempunyai keinginan untuk maju agar lebih baik. Oleh karena itu dorongan atau motivasi didalam belajar pendidikan agama Islam terutama pelajaran fikih yang bertujuan agar peserta didik mendapatkan hasil belajar yang baik dalam hukum dan syariat Islam. Karena itu dorongan dan motivasi yang diberikan pendidik dapat mempengaruhi perkembangan belajar peserta didik, untuk lebih baik lagi dan mengetahui hukum dan syariat Islam, Seperti: tentang tata cara Taharah, Zakat, Haji, Zina, Muamalah dan Jual beli.

Penggunaan media dalam proses belajar mengajar saat ini bukan lagi merupakan suatu hal yang baru dalam dunia pendidikan. Karena dengan adanya media, akan lebih meningkatkan pemahaman peserta didik dalam memahami materi pembelajaran. Sebagai alat bantu, media mempunyai fungsi memudahkan proses menuju tercapainya tujuan pembelajaran dan media juga digunakan sebagai alat metode, serta teknik yang

\footnotetext{
${ }^{1}$ Azhar Arsyad, Media Pembelajaran (Jakarta: PT Raja Grafindo Persada, 1996). Hal. 81

${ }^{2}$ Ibid. Hal. 15
}

Al Qalam: Jurnal Ilmiah Keagamaan dan Kemasyarakatan Vol. 14, No. 2, Juli-Desember 2020 
digunakan dalam meningkatkan efektifitas komunikasi dan interaksi edukatif antara pendidik dan peserta didik dalam proses pendidikan dan pembelajaran di sekolah.

Meskipun begitu pentingnya alat atau media untuk tercapainya tujuan pendidikan, masih banyak dijumpai lembaga-lembaga pendidikan yang masih belum memperhatikan alat atau media tersebut. Terbukti banyak ditemukan kasus pendidik yang belum mempergunakan media sesuai dengan bahan yang diajarkan. Sehingga peserta didik mengalami banyak hambatan dalam menyerap dan memahami materi pelajaran yang disampaikan, serta banyak siswa yang merasa bosan terhadap penjelasan pelajaran tertentu. Hal ini dapat dikatakan sebagai masalah kurangnya penggunaan media dalam pembelajaran.

Pendidik yang menempati kedudukan central, beliau harus mengaplikasikan dan melakukan nilainilai yang terdapat didalam sebuah kurikulum disekolah, kemudian mentransformasikan nilai-nilai tersebut pada peserta didik, melalui proses pembelajaran. ${ }^{3}$ Bila kita berbicara masalah tentang pembelajaran tentu ini merupakan proses yang sedang berlangsung terjadinya kegiatan interaksi anatara 2 orang atau lebih. "Belajar adalah key term ( Istilah kunci ) yang paling vital dalam setiap usaha pendidikan, sehingga tanpa belajar sesungguhnya tak pernah ada pendidikan."

Metode pembelajaran itu mimiliki banyak model diantaranya: Metode diskusi, ceramah, PBL, Jigsaw dan metode pembelajaran merupakan salah satu metode yang dapat digunakan pendidik dalam menyampaikan materi yang berhubungan dengan pembelajaran Fikih, dan metode ini dapat digunakan pendidik untuk membuat peserta didik menjadi lebih paham dan aktif dalam pembelajaran Fikih. Sehingga metode pembelajaran ini dapat diterapkan dalam pembelajaran Fikih di MA Al-Khoirot.

Metode pembelajaran diskusi yaitu metode yang menggabungkan cara belajar aktif yang berorientasi pada proses dan mengarahkan siswa lebih mandiri, dan reflektif, serta berusaha memberi pengalaman belajar pada peserta didik. Dengan demikian dapat dikatakan bahwa metode diatas adalah suatu metode di mana dalam pembelajaran guru memperkenankan peserta didiknya untuk menerapkan apa yang ia pelajari.

Proses pembelajaran fikih selama ini yang berlangsung di MA Al-Khoirot yaitu menggunakan metode pembelajaran yang telah disebutkan, untuk penerapan di MA Al-Khoirot. Peserta didik dihadapkan pada menerapkan seperti yang sudah ada, setelah itu peserta didik mencari penyelesaian atas kasus tersebut. Penyelesaian dilakukan secara berkelompok. Setelah selesai dipresentasikan dengan diskusi.

Dengan adanya Kesenjangan antara tujuan pembelajaran dengan kenyataan pembelajaran fikih di MA Al-Khoirot, maka mendorong peneliti menerapkan suatu metode yang tepat pada proses pembelajaran, sebab fungsi metode dalam sistem pembelajaran adalah untuk mencapai tujuan pembelajaran. Untuk mengembangkan proses belajar, sebaiknya pendidik memberikan kesempatan pada peserta didik untuk meningkatkan dan mengembangkan kemampuannya. Jadi, tugas seorang pendidik bukan hanya memberi

\footnotetext{
${ }^{3}$ Agus Pahrudin, Strategi Belajar Mengajar Pendidikan Agama Islam Di Madrasah (Pendekatan Teoritis dan Praktis) (Fakta Press Fakultas Tarbiyah IAIN Raden Intan, Lampung, 2013). Hal 13

${ }^{4}$ Muhibin Syah, Psikologi Pendidikan (Bandung: PT Remaja Rosdakarya, 2001). Hal. 94
}

Al Qalam: Jurnal Ilmiah Keagamaan dan Kemasyarakatan Vol. 14, No. 2, Juli-Desember 2020 
pengetahuan (Knowledge), melainkan harus menyiapkan materi pembelajaran yang menggiring peserta didik untuk bertanya, mengamati, menganalisi, mengadakan eksperimen serta mengimplikasikan dalam keseharian.

Berdasarkan hasil observasi dilapangan, maka metode pembelajaran diatas merupakan metode yang sesuai dalam pembelajaran fikih. Maka dari itu peneliti membuat penelitian yang berjudul Implementasi Media Dan Metode Pembelajaran Dalam Penguasaan Materi Fikih Di MA Al-Khoirot. Dengan demikian pendidik bisa meningkatan keterampilan dalam pembelajaran mengunakan media dan metode pembelajaran yang baik.

\section{METODE PENELITIAN}

Jenis Penelitian yang dilakukan adalah penelitian kualitatif. Metode penelitian ini diartikan sebagai cara untuk mendapatkan data dengan tujuan dan kegunaan tertentu. Untuk desain penelitian yang dilakukan adalah penelitian lapangan (field reseach) yaitu peneliti turun kelapangan untuk medapat data. Peneliti melakukan penelitian lapangan di MA Al-Khoirot, yaitu pada guru Fikih di MA Al-Khoirot. Penelitian langsung terjun kelapangan bertujuan untuk mempelajari secara langsung latar belakang masalah, status terakhir, dan interaksi lingkungan yang terjadi pada suatu satuan sosial seperti individu, kelompok, lembaga, atau komunitas. ${ }^{5}$ Sedangkan pendekatan yang digunakan dalam penelitian ini yaitu pendekatan kualitatif. Metode kualitatif adalah mengamati orang dalam berinteraksi dengan mereka, berusaha memahami bahasa dan tingkah mereka tentang dunia sekitarnya. ${ }^{6}$

Penelitian berpandangan berlandaskan filsafat postpositivisme, yang digunakan untuk meneliti obyek yang alamiah, yaitu guru fikih di MA Al-Khoirot, peserta didik dan kegiatan pembelajaran. Penelitian ini peneliti sebagai instrumen kunci. Adapun analisis data dalam penelitian kualitatif ini bersifat induktif dan hasil penelitian lebih menekankan makna dari pada generalisasi. ${ }^{7}$ Adapun Sumber data untuk penelitian ini yaitu menggunakan sumber primer dan sekunder. Sumber primer adalah sumber data yang secara langsung memberikan data kepada pengumpul data, misalnya melalui wawancara langsung dengan guru mata pelajaran, kepala sekolah. Sedangkan untuk sumber sekunder merupakan sumber yang tidak langsung memberikan data kepada pengumpul data misalnya lewat orang lain atau lewat dokumen. ${ }^{8}$ Untuk Pengumpulan data yaitu mengunkan prosedur yang sistematik dan standar untuk memperoleh data yang diperlukan. ${ }^{9}$ Peneliti menggunakan beberapa pendekatan untuk memperoleh data, diantaranya: Observasi (pengamatan), Wawancara (Interview) dan Dokumentasi. Dan untuk tehnik keabsahan data dan analisis uji

\footnotetext{
${ }^{5}$ Sugiono, Metode Penelitian Pendidikan "Pendekatan Kuantitatif, Kualitatif dan R\&D (Bandung: Alfabeta, 2014). Hal. 5

${ }^{6}$ Nasution, Metode Penelitian Naturalistic Kualitatif (Bandung: Tarsito, 1998). Hal. 8

${ }^{7}$ Ibid. Hal. 15.

${ }^{8}$ Ibid, Hal.193.

${ }^{9}$ W Gulo, Metode Penelitian (Jakarta: PT Grasindo, 2010). Hal. 116
}

Al Qalam: Jurnal Ilmiah Keagamaan dan Kemasyarakatan Vol. 14, No. 2, Juli-Desember 2020 
kredibilitas data penelitian ini mengunakan tahapan antara lain: Triangulasi dalam pengujian kredibilitas ini diartikan sebagai pengecekan data dari berbagai sumber dengan berbagai cara, dan berbagai waktu. Menggunakan bahan referensi, memperpanjangan pengamatan dan Meningkatkan ketekunan. ${ }^{10}$

Untuk Teknik Analisis data yaitu proses mencari dan menyusun secara sistematis yang diperoleh dari hasil wawancara, catatan lapangan, materi-materi lain yang telah dikumpulkan untuk meningkatkan hasil penelitian mengenai materi dan untuk memungkinkan menyajikan apa yang sudah ditemukan. ${ }^{11}$ Dari data-data yang sudah didapatkan oleh peneliti dari lapangan, kemudian peneliti menganalisa dan menghubungkan dengan teori yang telah diungkapkan sebagai dasar acuan dalam penelitian kali ini. maka untuk analisis data peneliti menggunakan dua tahap: Pertama, Reduksi data (data reduction) Kedua, Penyajian data (Data Display). ${ }^{12}$

\section{HASIL PENELITIAN DAN PEMBAHASAN}

Kegiatan pembelajar melalui media bertujuan untuk memanfaatkan media sebagai sumber belajar. "Media dalam pengertian keseluruhan dapat mencakup barang, alat, benda dan manusia yang dapat dijadikan sumber belajar". Kegiatan pembelajaran melalui media dapat menggunakan media yang sudah ada dan media yang dirancang. ${ }^{13}$

Menurut Wina Sanjaya menjelaskan bahwa ada dua pandangan tentang belajar, yaitu: "belajar sering dikatakan atau dianggap sama dengan menghafal, dan belajar juga sering diartikan atau dianggap sebagai suatu proses perubahan perilaku sebagai akibat pengalaman dan Latihan. ${ }^{14}$ Media pengajaran adalah alat metode dan teknik yang yang digunakan dalam untuk mengefektifkan komunikasi dan interaksi antara guru dan siswa dalam proses pendidikan dan pengajaran di sekolah.

Fungsi Media Pembelajaran yaitu sebagai sumber belajar "Dapat diartikan bahwa salah satu fungsi utama media pembelajaran adalah sebagai alat bantu mengajar yang turut mempengaruhi iklim, kondisi, dan lingkungan belajar yang ditata dan diciptakan oleh guru". ${ }^{15}$ Dengan demikian di dalam proses pembelajaran media Pembelajaran dapat dikelompokan menjadi 4 kelompok besar yaitu: Media Audio, Media Visual, Media Audio Visual dan Media multimedia.

Menurut Zuhairini, Memberikan pengertian tentang metode diskusi yaitu sebagai salah satu metode interaksi edukatif yang diartikan sebagai metode didalam mempelajari bahan atau penyampaian bahan

\footnotetext{
${ }^{10}$ Lexy J Moleong, Metodologi Penelitian Kualitati (Bandung: PT. Remaja RosdaKarya, 2009). Hal. 329

${ }^{11}$ Emzir, Metodologi Penelitian Kualitatif Analisis Data (Jakarta: Raja Grafindo Persada, 2014). Hal. 85

${ }^{12}$ Sugiyono, Op.Cit, Hal. 336.

${ }^{13}$ Agus Pahrudin,Op.Cit, Hal. 35

${ }^{14}$ lyas ismail, Ilmu Pendidikan Praktis, (Jakarta: ganeca exact, 2008). Hal. 5

15 Azhar Arsyad, Op.Cit. Hal. 15
}

Al Qalam: Jurnal Ilmiah Keagamaan dan Kemasyarakatan Vol. 14, No. 2, Juli-Desember 2020 
pembelajaran dengan jalan mendiskusikannya sehingga menimbulkan pengertian, pemahaman, serta perubahan tingkah laku siswa seperti yang telah dirumuskan dalam tujuan instruksionalnya. ${ }^{16}$

Metode diskusi dalam dunia pendidikan ini mendapat perhatian karena dengan diskusi akan merangsang anak-anak untuk berfikir atau mengeluarkan pendapatnya sendiri. Oleh karena itu metode diskusi bukanlah hanya percakapan atau debat biasa saja, akan tapi diskusi timbul karena adanya masalah yang memerlukan jawaban atau pendapat yang berbeda-beda.

Adapun tujuan metode pengertian fikih menurut bahasa arab ialah Paham atau pengertian. "Sedangkan menurut istilah fikih adalah "Ilmu untuk mengetahui hukum-hukum syara' yang pada perbuatan anggota diambil dari dalil - dalilnya yang terperinci". ${ }^{17}$ Dari Pengertian di atas dapat dijelaskan bahwa ilmu fikih merupakan salah satu faktor untuk memperjelas hukum-hukum agama islam, sehingga nantinya siswa akan memahami dasar-dasar hukum agama islam, yang pada akhirnya dapat melaksanakan tugas dan kewajibannya dalam kehidupan sehari-hari dan bermasyarakat sesuai dengan aturan agama Islam yang berbasis agama. Dan jam mata pelajaran agama yang disajikan lebih besar dibandingkan dengan sekolahsekolah umum lainnya.

Adapun untuk implementasi media pembelajaran sebagai sumber belajar secara teknis, sedangkan pengaruh terhadap penggunaan media terhadap evektivitas pembelajaran fikih siswa di kelas sangat berpengaruh yakni sebagai penyalur, pemahaman dan digunakan sebagai penghubung. Melalui media pembelajaran pendidik/guru dapat menyajikan bahan pelajaran yang bersifat abstrak menjadi konkrit sehingga mudah dipahami dan dapat menghilangkan verbalisme. Misalkan seperti contoh untuk menyampaikan bahan pelajaran tentang sistem peredaran darah pada manusia dapat disajikan melalui Vidio. ${ }^{18}$ Berdasarkan pendapat diatas bahwa Pengaruh penggunaan media terhadap prestasi belajar peserta didik sangat besar peranannya, karena media dapat merangsang sekaligus menjadi daya tarik peserta didik/siswa, sehingga peserta didik dapat dengan mudah untuk menerima materi pendidik/guru dalam menyampaikan materi dalam proses kegiatan belajar mengajar.

\section{Penerapan Media Pembelajaran Mata Pelajaran Fiqih di MA Al-Khoirot}

Penerapan media pembelajaran pada mata pelajaran fikih, yaitu agar guru lebih mudah menjelaskan materi pembelajaran dan bagi siswa lebih memahami secara nyata dalam pembelajaran serta menciptakan kelas menjadi lebih kondusif, nyaman, tidak membosankan dan menyenangkan dalam belajar.

Media Pembelajaran berfungsi sebagai sumber belajar dan sebagai sarana pendidik untuk menyampaiakan kegiatan belajar mengajar di sekolah, kepada peserta didik. Oleh karna itu diharapkan

\footnotetext{
${ }^{16}$ Sumanto al-Qurtuby, K.H MA. Sahal Mahfudh; Era baru Fiqih Indonesia, (Yogyakarta: Cermin, 199M). Hal. 199

${ }^{17}$ Sulaiman Rasid, Fiqih Islam (Bandung: Sinar Baru, 1992). Hal. 22

${ }^{18}$ Sanjaya Wina, Strategi Pembelajaran Berorientasi Standar Proses Pendidikan (Bandung: Kencana, 2006). Hal, 170
}

Al Qalam: Jurnal Ilmiah Keagamaan dan Kemasyarakatan Vol. 14, No. 2, Juli-Desember 2020 
dengan menggunakan media pembelajaran peserta didik akan dengan mudah menerima materi yang telah disampaikan oleh pendidik di MA Al-Khoirot. Media mempunyai fungsi sebagai jalan menuju tercapainya tujuan pembelajaran dan media juga digunakan sebagai alat, metode serta teknik yang digunakan dalam rangka meningkatkan efektifitas komunikasi dan interaksi edukatif antara guru dan siswa dalam proses pendidikan dan pembelajaran di sekolah.

Temuan pada penggunaan media pembelajaran adalah masih banyak dijumpai lembaga-lembaga pendidikan yang kurang mementingkan suatu alat atau media pembelajaran tersebut. Terbukti banyak ditemukan kasus guru yang tidak mempergunakan media sesuai dengan bahan yang diajarkan. Sehingga siswa mengalami banyak kesulitan dalam menyerap dan memahami materi yang disampaikan guru serta banyak siswa yang merasa bosan terhadap pelajaran tertentu.

Untuk penerapan metode pembelajaran pada mata pelajaran fikih yang berlangsung di MA AlKhoirot yaitu: diskusi, ceramah, tanya jawab, PBL. Memiliki beberapa mata pelajaran, namun disini peneliti memfokuskan pada mata pelajaran fikih. Materi fikih merupakan mata pelajaran yang sangatlah penting bagi peserta didik karena berisi tentang penjelasan hukum-hukum agama Islam mengenai segala hal mulai tata cara ibadah kepada Allah hingga hukum muamalah. Pembelajaran Fikih di MA Al-Khoirot sudah mengikuti kurikulum 2013 semenjak tahun 2018, sebagaimana yang disampaikan oleh waka kurikulum Bapak David Fermandi, M. Pd: Mulai dari kelas X, XI dan XII kita sudah menggunakan kurikulum 2013.

Dalam langkah pelaksanaan pembelajaran Fikih melalui lima tahapan diantaranya: Introduction, yaitu penjelasan tujuan pembelajaran, dan apa yang akan dicapai selama proses pembelajaran. Conection, yaitu pendidik berusaha menghubungkan materi bahan ajar yang baru dengan sesuatu yang sudah diketahui oleh para peserta didik. Selanjutnya application, yaitu peserta didik diberi kesempatan untuk mempraktikkan dan menerapkan pengetahuan.

Berdasarkan dari penjelasan diatas dapat diambil kesimpulan bahwa penerapan metode pembelajaran fikih, diterapkan dengan cara guru terlebih dahulu membagi materi kedalam sub topik bahasan, kemudian mengelompokkan siswa disesuaikan dengan jumlah sub topik yang akan disampaikan dan mengatur ruang kelas secara keseluruhan supaya tercipta kelas yang aktif, aman, nyaman, inovatif, dan kondusif.

\section{Implementasi Media Pembelajaran Pelajaran Fikih di Ma Al-Khoirot}

Metode diartikan sebagai kerangka konseptual yang digunakan sebagai pedoman dalam melakukan suatu kegiatan, dari pengertian tersebut maka Metode pembelajaran adalah kerangka konseptual dan prosedur yang sistematik dalam mengorganisasikan pengalaman belajar untuk mencapai tujuan belajar tertentu, berfungsi sebagai pedoman bagi perancang pengajaran, serta para guru dalam merencanakan dan melaksanakan aktivitas belajar mengajar. Dengan demikian, aktivitas belajar mengajar benar-benar merupakan kegiatan bertujuan yang tersusun secara sistematis. ${ }^{28}$ Pembelajaran atau pengajaran adalah upaya guru untuk menyampaikan materi kepada siswa. Dalam pengertian ini secara sederhana dalam 
pengajaran terdapat kegiatan memilih, menetapkan, mengembangkan metode untuk mencapai hasil pengajaran yang diinginkan. Pemilihan, penetapan dan pengembangan metode ini didasarkan pada kondisi pengajaran yang ada. ${ }^{29}$ Sebagaimana yang diterapkan oleh guru fikih bahwa dalam pembelajaran fikih yang dilaksanakan sudah berjalan dengan baik, peserta didik aktif dan merespon dengan baik, dengan tersedianya fasilitas yang menunjang sehingga membantu berlangsungnya proses pembelajaran.

Langkah-langkah pembelajaran Fikih pada mata pelajaran Fikih di Ma. Al-Khoirot yaitu, meliputi beberapa langkah pembelajaran diantaranya: perencanaan, pelaksanaan dan evaluasi pembelajaran. Dalam proses pembelajaran terutama pada pembelajaran fikih guru menggunakan beberapa Metode dan metode pembelajaran agar dalam proses pembelajaran tidak membosankan dan jenuh. Salah satunya Metode pembelajaran gabungan yang merupakan suatu urutan dari kesatuan antara lain: pengenalan menghubungkan, penerapan, refleksi, perluasan belajar.

Metode pembelajaran yang dilaksanakan di MA Al-Khoirot terdiri dari tiga langkah Pertama, Tahap perencanaan yaitu guru membuat RPP termasuk memilih mempersiapkan alat dan media sebelum pembelajaran. Kedua, Tahap Pelaksanaan yaitu suatu langkah saat proses pembelajaran dengan menerapkan apa yang sudah direncanakan sebelumnya dalam RPP termasuk didalamnya terdapat introduction, connection, application, reflection, extension. Selanjutnya yang Ketiga, yaitu langkah evaluasi atau penilaian.

Berdasarkan hasil analisis peneliti maka faktor pendukung dalam pembelajaran di MA Al-Khoirot meliputi:

a. Faktor media atau sarana pendukung pembelajaran yakni tersedianya sarana prasarana seperti LCD, internet dan lain-lain,

b. Faktor ketepatan guru dalam mengunakan metode pembelajaran agar tercipta pembelajaran yang efektif dan nyaman,

c. Faktor keadaan kelas yang nyaman, tersedianya alat, media dan sember belajar

d. Faktor siswa yang aktif dan kooperatif

Jadi kesimpulan dari pemaparan diatas adalah jika dari keempat faktor diatas semua terpenuhi maka proses pembelajaran akan tersampaikan dengan baik.

\section{KESIMPULAN}

Maka mengambil kesimpulan berdasarkan hasil penelitian, penyajian dan analisis data tentang Implementasi Media Dan Metode Pembelajaran Dalam Penguasaan Materi Fikih Di MA Al-Khoirot. Untuk implementasi Penguasaan Media Pembelajaran materi Fikih di MA Al-Khoirot sudah diterapkan namun masih ada kendala dan kekurangan yaitu guru belum semua menguasai media pembelajaran. Dan untuk implementasi Penguasaan metode Pembelajaran materi Fikih di Ma Al-Khoirot sudah dicoba mengunkan semua metode yang ada namun pelaksanaannya selalu menggunakan metode caramah (demostrasi).

Al Qalam: Jurnal Ilmiah Keagamaan dan Kemasyarakatan Vol. 14, No. 2, Juli-Desember 2020 
Adapun Faktor-faktor pendukung dalam menerapkan media dan metode pembelajaran yaitu: ketepatan guru dalam menerapkan metode, tersedianya sumber dan bahan ajar yang mendukung sumber mata pelajaran fikih. Tersedianya alat peraga atau media untuk mendukung proses pembelajaran fikih, Siswa yang aktif, kooperatif dalam pembelajaran serta alokasi waktu yang tepat pada tiap kegiatan pembelajaranya.

\section{DAFTAR PUSTAKA}

Arsyad, Azhar. Media Pembelajaran. Jakarta: PT Raja Grafindo Persada, 1996.

Emzir. Metodologi Penelitian Kualitatif Analisis Data. Jakarta: Raja Grafindo Persada, 2014.

Gulo, W. Metode Penelitian. Jakarta: PT Grasindo, 2010.

ismail, lyas. Ilmu Pendidikan Praktis, Jakarta: ganeca exact, 2008.

Moleong, Lexy J. Metodologi Penelitian Kualitati. Bandung: PT. Remaja RosdaKarya, 2009.

Nasution. Metode Penelitian Naturalistic Kualitatif. Bandung: Tarsito, 1998.

Pahrudin, Agus. Strategi Belajar Mengajar Pendidikan Agama Islam Di Madrasah (Pendekatan Teoritis dan Praktis). Fakta Press Fakultas Tarbiyah IAIN Raden Intan, Lampung, 2013.

Qurtuby, Sumanto al-. K.H MA. Sahal Mahfudh; Era baru Fiqih Indonesia,. Yogyakarta: Cermin, 199M.

Rasid, Sulaiman. Fiqih Islam. Bandung: Sinar Baru, 1992.

sugiono. Metode Penelitian Pendidikan "Pendekatan Kuantitatif, Kualitatif dan R\&D. Bandung: Alfabeta, 2014.

syah, muhibin. Psikologi Pendidikan. Bandung: PT Remaja Rosdakarya, 2001.

Wina, Sanjaya. Strategi Pembelajaran Berorientasi Standar Proses Pendidikan. Bandung: Kencana, 2006.

Al Qalam: Jurnal Ilmiah Keagamaan dan Kemasyarakatan Vol. 14, No. 2, Juli-Desember 2020 